\title{
Financial Statement Fraud: Lessons Learned from Selected U.S. Legal Cases in the past Twenty Years
}

\begin{abstract}
Stephen Errol Blythe
Tarleton State University

The researcher analysed selected U.S. court cases of financial statement fraud from the past twenty years and concluded: (1) U.S. laws used to prosecute financial statement fraudsters include the Securities Act, Securities Exchange Act, S.E.C. Rule 10b-5, Investment Advisers Act, Private Securities Litigation Reform Act, and the Sarbanes-Oxley Act; (2) financial statement fraud schemes included use of unconsolidated special-purpose entities to conceal debt, improper revenue recognition in leasing of bandwidth in the telecom industry, improper accounting for goodwill in a merger, failure to write off a large amount of bad receivables, excessive recognition of revenue in bundled leases in the photocopier industry, use of loss contingency reserves to inflate current income, use of fictitious revenue to overstate earnings, and capitalising a project's operating expenses to hide cost overruns; (3) to be liable for financial statement fraud, a corporate officer must have knowledge; and (4) employees discharged for reporting financial statement fraud may sue under the Sarbanes-Oxley Act.
\end{abstract}

Key words: financial, statement, fraud, legal, cases

\section{Objectives}

The objectives of this article are to: (1) briefly review the literature of financial statement fraud; (2) define financial statement fraud and describe its primary characteristics; (3) determine the U.S. statutes and regulations that financial statement fraudsters are most often prosecuted under; (4) describe the most common types of financial statement fraud schemes in the past twenty years; (5) determine whether a corporate officer may be held legally liable for financial statement fraud if she had no knowledge of the fraud; and (6) state the required legal elements of a case of wrongful discharge of an employee who was terminated after reporting financial statement fraud to her superiors.

\section{Review of the literature}

Financial statement frauds occur with reporting of fictitious account balances or the deliberate misapplication of accounting standards (Rezaee, 2002; Spathis, Doumpos \& Zopoundidis, 2002). Auditors find it extremely difficult to detect fraud (Albrecht, Albrecht \& Dunn, 2001; Loebbecke, Eining \& Willingham, 1989). Accordingly, it is important for auditors to understand the relative frequency of various fraud schemes and how those schemes are perpetrated and concealed, which should result in a better assessment of overall fraud risk (Nelson, Elliott \& Tarpley, 2003; Bonner, Palmrose \& Young, 1998; Smith \& Kida, 1991; Heiman,

Stephen Errol Blythe, associate professor, Accounting and Business Law, Department of Accounting, Finance and Economics, College of Business, Tarleton State University, Stephenville, Texas USA. 
1990; Libby \& Frederick, 1990). In addition to the manipulation of account balances, fraud schemes often involve creation or hiding of evidence in order in order to cover up the fraud and to deceive auditors (Gao \& Srivastava, 2008). Improper revenue recognition is the most common type of financial statement fraud scheme, followed by overstatement of existing assets or the capitalisation of expenses. A variety of techniques have been used to overstate revenue: sham sales, conditional sales, recording loans as sales, bill-and-hold, recording as a sale before all terms of the sales agreement are satisfied, improper cut-off, improper application of the percentage of completion method, unauthorised shipments and consignment sales (Beasley, Carcello \& Hermanson, 2010). ${ }^{1}$

\section{Definition of financial statement fraud}

Financial statement fraud is defined as deliberate misstatements or omissions of amounts or disclosures of financial statements to deceive financial statement users, especially investors and creditors. Financial statement fraud schemes include: (1) falsification, alternation or manipulation of financial records, related documents or business transactions; (2) intentional omissions or misrepresentations of events, transactions, accounts or other information from which financial statements are prepared; (3) deliberate misapplication of accounting principles, policies and procedures used to measure, recognize, report and disclose economic events and business transactions; and (4) intentional omissions of disclosures or presentation of inadequate disclosures pertaining to accounting principles and policies and related financial amounts. ${ }^{2}$

\section{The relevant U.S. law}

During the past twenty years, U.S. financial statement fraudsters have been most commonly prosecuted for violation of these federal statutes and regulations:

\section{Securities Act of 1933}

It is illegal to make any untrue statement of a material fact or to omit a material fact in connection with the purchase or sale of any security in an initial public offering; there is a strict liability standard with no scienter requirement. $^{3}$

\section{Securities Exchange Act of 1934 § 10(b)}

The use of a manipulative or deceptive device or contrivance in the purchase or sale of a security is prohibited. ${ }^{4}$ The purpose of $\S 10$ (b) is "to substitute a philosophy of full disclosure for the philosophy of caveat emptor and thus to achieve a high standard of business ethics in the securities industry.",

\section{Securities Exchange Commission, Rule 10b-5}

It is illegal to make any untrue statement of a material fact or to omit a material fact in connection with the purchase or sale of any security after the initial public offering; a plaintiff is required to prove that a defendant acted with scienter. ${ }^{6}$ The majority of securities fraud claims are brought pursuant to Rule $10 \mathrm{~b}-5$ for false or

${ }^{1}$ Clement C.M. Ajekwe \& Adzor Ibiamke, “Accounting Frauds: A Review of Literature,” 22:4 IOSR Journal of Humanities and Social Science 38, 42-43 (2017); www.iosrjournals.org .

2 Joseph T. Wells, Principles of Fraud Examination (Hoboken, N.J.: John Wiley \& Sons, Inc., 2014), p. 305.

315 U.S.C. §§ 77k et seq.

4 15 U.S.C. $\$ 78 \mathrm{j}(\mathrm{b})$.

${ }^{5}$ Affiliated Ute Citizens of Utah v. United States, 406 U.S. 128, 151 (1972), citing SEC v. Capital Gains Research Bureau, Inc., 375 U.S. 180, 186 (1963).

${ }^{6} 17$ C.F.R. § $240.10 b-5$. 
misleading statements or omissions. In order for a claim under this provision to survive a motion to dismiss, a plaintiff must allege that the defendant, "in connection with the purchase or sale of securities, made a materially false statement or omitted a material fact, with scienter, and that the plaintiff's reliance on the defendant's action caused injury to the plaintiff." ${ }^{, 7}$

\section{Securities Exchange Act of 1934, § 20(a)}

A control person of a primary violator may be held liable if plaintiff proves (1) a primary violation by the controlled person, (2) control of the primary violator by defendant, and (3) defendant was a culpable person in the controlled person's fraud. Where there is no primary violation, there can be no "control person" liability. ${ }^{8}$

\section{Private Securities Litigation Reform Act}

This statute limits the extent to which an external auditor, only indirectly involved with any wrongdoing, may be held accountable for investors' losses. It provides for more stringent pleading requirements for a plaintiff in securities fraud cases. ${ }^{9}$

\section{Investment Advisers Act of 1940}

Investment advisers are required to be registered with the Securities and Exchange Commission and must comply with specific registration procedures and requirements. ${ }^{10}$

\section{Sarbanes-Oxley Act of 2002}

This statute requires the chief executive officer and chief financial officer of a publicly-traded entity to accept responsibility for their firm's financial statements by affixing their signatures to the corporate annual report. ${ }^{11}$ It also protects whistleblowers who report financial statement fraud to senior management. ${ }^{12}$

\section{The legal requirements in pleading a case of financial statement fraud in the United States}

Whenever a U.S. plaintiff alleges that a defendant firm's financial disclosures were false and misleading due to accounting improprieties, the standard for pleading accounting fraud must be addressed. To properly state a claim for accounting fraud, plaintiffs must plead facts sufficient to support a conclusion that the defendant firm prepared fraudulent financial statements and that the alleged financial fraud was material. ${ }^{13}$ Generally Accepted Accounting Principles (GAAP) violations can provide evidence of scienter. However, the complaint must describe the violations with sufficient particularity; a general allegation that the practices at issue resulted in a false report of company earnings is not a sufficiently particular claim of misrepresentation. ${ }^{14}$

When pleading irregularities in revenue recognition, plaintiffs should allege: (1) such basic details as the approximate amount by which revenue and net income were overstated; (2) the products involved in the contingent transaction; (3) the dates of any of the transactions; or (4) the identities of any of the customers or

\footnotetext{
${ }^{7}$ Ganino v. Citizens Utilities Co., 228 F.3d 154, 161 (2d Cir. 2000). A statement or omission is material if it "would have been viewed by the reasonable investor as having significantly altered the 'total mix' of information made available." TSC Industries, Inc. v. Northway, Inc., 426 U.S. 438, 449 (1976).

815 U.S.C. $\S \S 78(t)$ et seq.

9 15 U.S.C. $\$ 78 \mathrm{u}-4$.

1015 U.S.C. $\S \S 80 \mathrm{~b}-2$ et seq.

11 U.S.C. § 7241.

1218 U.S.C. § 1514A.

13 In re Daou Systems, Inc. Securities, 397 F.3d 704, 712 (9 $9^{\text {th }}$ Cir. 2005).

14 Id. at $712-13$.
} 
the firm's employees involved in the transaction. ${ }^{15}$ Although a plaintiff need not allege each of these particular details, he must allege enough to allow a court to discern whether the alleged GAAP violations were minor or technical in nature, or whether they constituted widespread and significant inflation of revenue. ${ }^{16}$ Thus, to support a claim of fraud, a plaintiff must plead with particularity how the accounting manipulations affected the firm's financial statements and whether they were material in view of the firm's overall financial position. ${ }^{17}$

\section{Types of financial statement fraud, with cases}

Arthur Andersen's strike one:

Enron's fraudulent use of special-purpose entities to conceal massive debt and the existence of a Ponzi scheme

Enron Corporation's shareholders and holders of debt securities brought a derivative action against Enron. They alleged that Enron violated the Securities Act of 1933, the Securities and Exchange Act of 1934, SEC Rule 10b-5 and the Texas Securities Act. ${ }^{18}$ During 1998-2001, Enron Corporation's senior management fraudulently manipulated Enron's publicly reported financial statements. Their purpose was to mislead investors and others about the true financial position of Enron and inflate the price of Enron stock and maintain its credit rating. Four special purpose entities (SPEs) were used to hide massive debt. Those SPEs were purportedly independent of Enron and were ostensibly to be used to hedge the value of certain assets, but in fact they were not sufficiently independent of Enron and should have been included in its consolidated financial statements, instead of being deconsolidated. As a result, Enron dramatically overstated its earnings because a large amount of corporate debt was transferred from Enron to its SPEs. Members of senior management pilfered large amounts of cash from Enron during this period and Enron was transformed from an energy company to a Ponzi scheme. ${ }^{19}$

During 1997-2000, Arthur Andersen LLP (Andersen) had been Enron's external auditor and had issued unqualified opinions on Enron's financial statements. In late 2001, the Ponzi scheme began to unravel. Enron announced a press release and filed an SEC Form 8-K revealing that Enron would restate its financial statements for the period beginning January 1, 1997 through June 30, 2001. Enron also stated the previously issued financial statements for those periods were incorrect and Andersen's audit opinions issued during that time could not be relied upon. The Form 8-K indicated: (1) a reduction of \$1.2 billion in shareholder's equity; (2) an overstatement of profits by more than $\$ 591,000$; (3) an understatement of debt by $\$ 591$ million; and (4) an admission that the SPEs should have appeared on Enron's consolidated financial statements. ${ }^{20}$ Enron announced it was under SEC investigation on October 31, 2001 and was forced to declare bankruptcy on December 2, 2001. ${ }^{21}$

Andersen had been aware of the violations of GAAP at Enron and that the SPEs had been improperly used to hide debt for several years. Nevertheless, Andersen continued to issue unqualified opinions during this period. In a desperate attempt to hide its culpability, Andersen engaged in spoliation of evidence when it

15 Id. at 713 .

16 In re McKesson HBOC, Inc. Securities Litigation, 126 F.Supp. 1248, 1273 (N.D.Cal. 2000).

17 Note 1 at 714 .

18 In re Enron Corporation Securities, Derivative \& ERISA Litigation, 235 F.Supp.2d 549, 563 (S.D. Tex. Houston Div., 2002).

19 Newby v. Enron Corp. (In re Enron Corp. Securities Derivative \& "Erisa” Litigation), Civil Action Nos. H-01-3624 and G-03-0967 at 67 (S.D.Tex. 2010).

20 Id. at 85.

21 CNN Library, “Enron Fast Facts,” updated April 23, 2018; https://www.cnn.com/2013/07/02/us/enron-fast-facts/index.html . 
destroyed some of the incriminating documents relating to its Enron audits. ${ }^{22}$ Andersen was criminally convicted of obstruction of justice in 2002. With its reputation in tatters, the firm was forced to surrender its CPA license and to close its doors in $2002{ }^{23}$

Arthur Andersen's strike two: at Andersen's recommendation,

Global Crossing improperly accounted for IRU transactions to hide

the fact that its multi-billion dollar revenues and strong cash flow was a sham

The stockholders of Global Crossing, Ltd. (GC), a telecommunications company, filed a derivative action against GC, its individual directors and officers, and GC's external auditor, Arthur Andersen LLP (Andersen) and several of its officers, board members and employees. ${ }^{24}$ This class action arose from accounting improprieties during 1999-2002 that artificially inflated the firm's stock price. Insiders sold over \$1.5 billion of the artificially inflated GC stock while in possession of material, non-public information that GC's purported multi-billion dollar revenues and strong, substantial cash flow were a complete sham. ${ }^{25}$

The claims against Andersen centered around fraudulent misstatements of GC's assets, obligations and cash revenues, arising from the manner in which GC accounted for certain transactions involving "indefeasible rights of use" (IRUs). An IRU is the right to use a specified bandwidth over a designated communications cable owned by a telecommunications firm for a set period of time. Income from IRU transactions represented a large portion of GC's revenues during the class period and played a substantial role in determining the market value of their shares. In its role as auditor, Andersen was alleged to have perpetrated a fraud on investors by dictating incorrect and misleading accounting systems for these transactions and by structuring them so as to inflate GC's reported earnings, in violation of GAAP and Generally Accepted Auditing Standards (GAAS). There were two aspects of Andersen's improper accounting for IRUs: (1) GC's receipt of money paid in advance for an IRU should have been recognized as revenue pro rata over the 25-year-life of the IRU, instead of being reported as immediate cash revenue, and the related IRU expenses should also have been amortized over the IRU's 25-year life; and (2) similarly reported income from unneeded reciprocal "swaps" with other carriers of such capacity, notwithstanding that, where cash actually changed hands, it was "round-tripped" in the return half of the swap, thereby yielding no actual revenue because GC was obligated to make a corresponding purchase from the other carrier later. Also, the value of the IRUs received in the swaps was dramatically overstated, because they were carried at or above fair market value even as the market price for capacity plummeted due to the glut on the market. ${ }^{26}$

Joseph Perrone, a senior partner in Andersen's media and communications practice, devised a "roadmap" whereby telecom firms, and GC in particular, could structure trades of capacity to create the appearance of revenue, with the purpose of avoiding GAAP requirements. In particular, the transactions were structured to circumvent Accounting Principles Board Opinion No. 29, “Accounting for Nonmonetary Transactions,” (APB 29) which specifies that no revenue or expense should be recorded for transactions that involve an exchange of like assets. Andersen's scheme advised that telecom clients could book revenue from IRU sales between firms if the transactions had separate contracts and separate cash settlements, and if the contracts were at least sixty

\footnotetext{
${ }^{22}$ Id. at 22.

${ }^{23}$ CNN Library, Note 14. The criminal conviction was later overturned on appeal by the U.S. Supreme Court, but the damage to Andersen's reputation was permanent and the firm did not re-open. Id.

${ }^{24}$ In re Global Crossing, Ltd. Securities Litigation, 322 F.Supp.2d 319 (S.D.N.Y. 2004).

${ }^{25}$ Id. at 324.

${ }^{26}$ Id. at 325-26.
} 
days apart. Thereafter, GC followed these Andersen- recommended guidelines to book revenue from the transactions, in violation of APB 29 and GAAP. This scheme caused the value of GC stock to skyrocket, but the GC shareholders incurred steep losses in 2002 when the house of cards collapsed and GC went bankrupt. ${ }^{27}$

Andersen, as GC's auditor, played a central role in devising and implementing the accounting scheme. Andersen created a web of interrelated transactions between its telecom clients that had no economic substance but which were used to fool investors into believing that the telecom industry and telecom firms were growing much faster than in reality. In addition to issuing unqualified audit opinions in GC's annual 10-K reports filed with the SEC, Andersen allegedly also had direct knowledge of GC's unaudited pro forma reports and was responsible for overseeing all of GC's public statements. Plaintiffs sought to hold Andersen liable under § 10(b) of the 1934 Act and Rule 10b-5 for the financial statements it audited during 1998-2000. Plaintiffs also sought to hold Andersen liable for GC's unaudited press releases and

"pro forma" disclosures, which included falsely optimistic statements of income. ${ }^{28}$ Andersen filed a motion to dismiss the lawsuit, but the court denied the motion. ${ }^{29}$

\section{Arthur Andersen's strike three: massive fraud at WorldCom-illegal capitalisation}

\section{of operating expenses and improper accounting for goodwill in a merger}

Arthur Andersen LLP (Andersen) served as external auditor of WorldCom, Inc., the second largest telecommunications company in the world, for more than twenty years. ${ }^{30}$ On March 24, 2000, Andersen issued an unqualified opinion on WorldCom's financial statements for 1999. Later, Andersen issued unqualified opinions for 2000 and $2001 .^{31}$

WorldCom announced on June 25, 2002 that as a result of an internal audit, it had determined that its financial statements for 2001 and the first quarter of 2002 were not in conformity with GAAP. On July 21, WorldCom filed for bankruptcy. After emerging from bankruptcy in 2005, WorldCom restated its financial statements for 2000 and 2001 with $\$ 76$ billion in adjustments. Andersen withdrew its opinion for the 2001 statements, but not for the 1999 or 2000 statements. $^{32}$

Because of Andersen's “clean” opinion of the WorldCom financial statements, Andersen was sued under the Securities Act of 1933 and the Securities and Exchange Act of 1934. After the close of discovery in that case, Andersen moved for partial summary judgment, arguing that: (1) there was insufficient evidence the 1999 financial statements were materially false, and even if they were false, it was not liable for the 1999 statements based on the due diligence defense and the fact that it complied with GAAS; and (2) there was no evidence it acted with scienter with respect to the audits of the three years. ${ }^{33}$

WorldCom's financial statements were fraudulent for two reasons: (1) senior management's illegal manipulation of the accounting for the largest category of its operating expenses (line costs, the expenses incurred for the transmission of voice and data over other carriers' networks) during 2001 and 2002 by shifting a portion of them to capital expenditure accounts—a violation of GAAP which was criminal and which was

${ }^{27}$ Id. at 326-27.

28 Id. at 327.

${ }^{29}$ Id. at 353.

${ }^{30}$ In re WorldCom, Inc. Securities Litigation, 352 F.Supp. 2d 472, 482 (S.D.N.Y. 2005).

31 Id. at 475 .

32 Id. at $475-76$.

${ }^{33}$ Id. at 475. 
actively concealed from Andersen; ${ }^{34}$ and (2) improper accounting of WorldCom’s merger with MCI in 1998 by adopting a forty year useful life for MCI's goodwill and failing to segregate from goodwill two other assets consisting of MCI's workforce and MCI's customer base and to apply the appropriate amortization bases to them—which had the effect of materially reducing the reporting of expenses by WorldCom in its 1999 financial statements. ${ }^{35}$

In 1999, in preparation for its audit engagement at WorldCom, Andersen had assessed WorldCom's management integrity to be only "fair" and had found there to be "significant" risk pertaining to accounting and financial reporting in that firm. Furthermore, in a brainstorming session, Andersen's audit team had predicted that the easiest way for WorldCom to commit accounting fraud would be through improper capitalisation of expenses, only of the very methods used by WorldCom. Therefore, Andersen was aware of the risk of fraud at WorldCom. ${ }^{36}$ The court held this amounted to adequate circumstantial evidence that Andersen had knowledge of the possibility of fraud at WorldCom. Furthermore, despite this knowledge, Andersen failed to take adequate steps to detect fraud. ${ }^{37}$ Therefore, Andersen's "due diligence” and scienter defenses were rejected by the court and the court denied Andersen's motion for partial summary judgment. ${ }^{38}$

\section{Arthur Andersen's strike four: concealment of millions of}

\section{dollars of receivables that should have been written off}

Adecco S.A. (“Adecco") and several of its senior managers were sued in a class action brought by Adecco's shareholders pursuant to the Securities and Exchange Act §§ 10(b) and 20(a) and Rule 10b-5.

Adecco is a Swiss firm providing personnel services under contracts with other firms in North America, Europe, Asia Pacific and Latin America. Adecco's stock trades on the Swiss Stock Exchange and is also traded as American Depositary Shares on the New York Stock Exchange. ${ }^{39}$

In March 2002, Adecco acquired Olsten Corporation, a U.S. firm, primarily for its more advanced technology. Adecco then terminated more than 600 of its most senior and most qualified North American executives, regional managers, and district managers in favor of Olsten's less qualified senior managers and executives. After the Olsten takeover, Adecco discovered it would be unable to collect millions of dollars in receivables from Olsten's customers, who had gone bankrupt or who had unresolved billing disputes. According to plaintiffs, Adecco should have written off the bad receivables, which totaled at least in the tens, if not hundreds, of millions of dollars. Another problem facing Adecco after the takeover was its inability and failure to match customer payments to proper invoices. When this occurred, many customers refused to pay new invoices. ${ }^{40}$

The combination of millions of dollars in uncollectible receivables and the amount that customers refused to pay resulted in hundreds of millions of dollars of outstanding receivables on Adecco's books during 2000 and 2001. In order to conceal the amount of bad debt it acquired in the Olsten merger and inflate the price of Adecco's stock, Adecco's senior managers misrepresented and omitted material facts in forms filed with the SEC and disseminated in press releases and conference calls. Plaintiffs maintain defendants engaged a variety

\footnotetext{
${ }^{34}$ Id. at 477 .

${ }^{35}$ Id. at 493.

${ }^{36} \mathrm{Id}$. at $482-83$.

${ }^{37}$ Id. at 494-95, citing Rombach v. Chang, 355 F.3d 164, 176 (2d Cir. 2004).

${ }^{38}$ Id. at 501.

39 Alaska Electrical Pension Fund v. Adecco S.A., 371 F.Supp. 1203, 1207-08 (S.D.Cal. 2005).

${ }^{40}$ Id. at 1208.
} 
of accounting shenanigans and failed to properly take allowances for doubtful accounts in its 2000 and 2001 financial statements. In particular, Adecco violated GAAP by applying new funds received from customers to old outstanding invoices. Plaintiffs also aver that Adecco manipulated its financial statements by billing customers at incorrect rates, improperly classifying its workers, engaging in State Unemployment Tax Act (SUTA) dumping, and delaying its payments to vendors. ${ }^{41}$

The outstanding and uncollectible receivables remained on Adecco's books until its balance sheet for the end of 2002, when Adecco began writing off the receivables that had been on its books for more than 90 days. Prior to that time, some uncollectible receivables had remained on Adecco's books more than two years. ${ }^{42}$

Adecco switched auditors from Arthur Andersen to Ernst \& Young (E\&Y) in late 2002. In early 2003, E\&Y warned defendants they needed to correct the misallocation of current cash receipts by year-end 2003 . However, defendants continued to engage in this practice until it learned E\&Y would not allow its lead auditor to approve the accounting scheme used by Adecco. ${ }^{43}$

On January 12, 2004, Adecco issued a press release entitled "Adecco S.A. Delays Announcement of FY 2003 Audited Results." The press release stated: "Reasons for the delay include: (1) the identification of material weaknesses in internal controls; (2) the resolution of possible accounting, control and compliance issues in the company's operations in certain countries; and (3) the completion of the company's efforts to address these matters and determine their effect on the company's financial statements. In this regard, an independent counsel has been appointed by the Audit \& Finance Committee of the company's Board of

Directors to conduct an independent investigation. The company is not yet able to predict when the audit of its consolidated financial statements will be completed." 44

Following this news, Adecco’s stock dropped from almost $\$ 17$ per share to as low as $\$ 10$ per share. American and Swiss authorities initiated investigations into possible violations of the law. ${ }^{45}$

On June 1, 2004, Adecco released its 2003 Annual Report. Adecco announced in this report that its financial statements received an unqualified opinion from its auditor and that no restatements of prior years were required and no evidence of material irregularities was found. Plaintiffs allege that Adecco's 2003 Annual Report conceded that problems in internal controls had existed. Adecco's Chairman, a defendant, stated that he hoped the "unfortunate episode" was ending, and that Adecco had "taken a number of significant steps to reinforce our audit and control functions throughout the company."46 Another defendant, Adecco's CEO, noted that the firm had "used this opportunity to review its operations and systems in the U.S. to improve the efficiency of its processes and to strengthen internal controls."

After the plaintiffs' complaint was filed, defendants filed a motion to dismiss. Claims brought under Rule 10b-5 and § 10(b) must meet Federal Rules of Civil Procedure 9(b)'s specificity requirement that "in all averments of fraud, the circumstances constituting fraud shall be stated with particularity." ${ }^{\text {"4 }}$ Also, a complaint alleging securities fraud must "specify each statement alleged to have been misleading, the reason or reasons

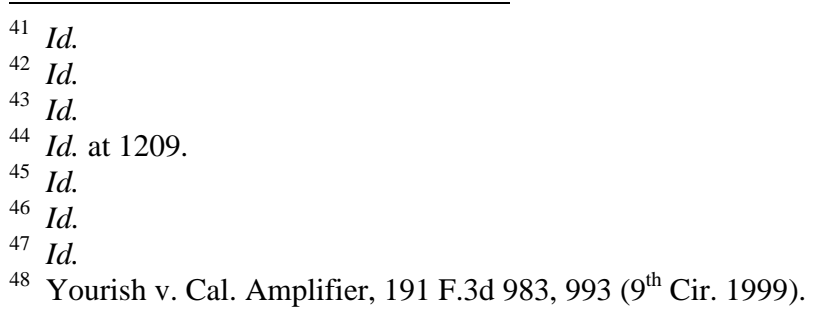


why the statement is misleading, and, if an allegation is made on information and belief, the complaint shall state with particularity all facts on which that belief is formed." ${ }^{49}$

The court held that plaintiffs' Rule 10b-5 and § 10(b) pleadings were deficient because they did not meet the particularity requirement. Furthermore, those pleadings were deficient because they failed to specify each statement that was allegedly misleading and how or why it was misleading. ${ }^{50}$ Additionally, the court held that since the Rule 10b-5 and § 10(b) claims failed, the § 20 claim would also fail because it was dependent upon the viability of the other two claims. ${ }^{51}$ Accordingly, the court granted defendants' motion to dismiss. However, this dismissal was without prejudice and plaintiffs were given 45 days to amend their complaint and to re-file it. $^{52}$

\section{Xerox's use of fraudulent lease accounting and improper loss}

\section{contingency reserves to misstate their financial statements by $\$ 3$ billion}

The SEC brought a lawsuit against KPMG LLP (KPMG) and several of its audit partners alleging they participated in a massive accounting fraud at Xerox Corporation (Xerox) during 1997-2000. ${ }^{53}$ The complaint alleges that these defendants permitted Xerox to manipulate its accounting practices in order to fill a $\$ 3$ billion gap between its actual operating results and the operating results reported to the public in its financial statements. In 2001, Xerox released a \$312 million restatement its 1998 and 1997 pretax earnings. In 2002, after the enormity of the fraud became public, Xerox issued a $\$ 6.1$ billion restatement of its equipment revenues and a $\$ 1.9$ billion restatement of its pre-tax earnings for the period 1997-2000. In 2004, KPMG reached a settlement with the SEC. KPMG: (1) consented to a finding that it violated Section 10A of the 1934 Act; (2) agreed to pay disgorgement of $\$ 9.8$ million, plus prejudgment interest; (3) agreed to pay a civil penalty of \$10 million; and (4) agreed to implement a number of internal reforms. One of the partners, defendant Boyle, settled with the SEC by paying a civil penalty of $\$ 100,000$ and was permanently enjoined from violating $\S 10 \mathrm{~A}$ of the 1934 Act. $^{54}$

The claims against the remaining partners were: (1) violations of $\S 17(\mathrm{a})$ of the 1933 Act and $\S 10(\mathrm{~b})$ of the 1934 Act; (2) aiding and abetting violations of $\S 10$ (b) of the 1934 Act; (3) violation of $\S 10 \mathrm{~A}$ of the 1934 Act; (4) aiding and abetting violations of $\S 13(\mathrm{a})$ of the 1934 Act; and (5) aiding and abetting violations of $\S$ 13(b) of the 1934 Act. The SEC sought permanent injunctions against the KPMG partners. In 2005, the partners filed motions for summary judgment, based on these theories: (1) they did not make false or misleading statements, a requirement for liability under the 1934 Act; (2) they face, at most, aiding and abetting liability under § 20(e) of the 1934 Act; (3) they are not liable under § 10A of the 1934 Act because that provision is inapplicable to individual accountants; and (4) two partners stated they should not incur $\S 10 \mathrm{~A}$ liability because they had reported Xerox's illegal acts to its audit committee. ${ }^{55}$

During 1997-2000, Xerox paid KPMG \$23 million in audit fees and \$56 million in consulting fees. In exchange, KPMG issued unqualified opinions on Xerox's financial statements during that period and "signed off" on two improper accounting practices: (1) the recognition of revenue too early in the term of the bundled

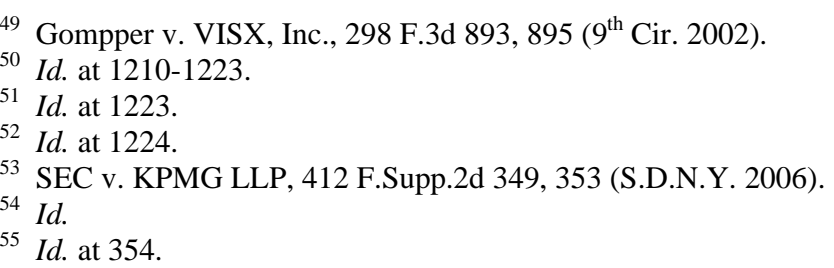


leases, in which a customer paid a single negotiated monthly fee for photocopier equipment, servicing and financing, effected through "return on equity" adjustments (which reallocated a portion of financing income to equipment revenue) and "margin normalisation" adjustments (which allocated a portion of service income to equipment revenue); and (2) the creation of unneeded loss contingency reserves (allowed under GAAP only if a future loss is both probable and reasonably estimable), which allowed Xerox to draw on the reserve to cover expenses for which the reserve was not created and thereby artificially boost its earnings in subsequent reporting periods. $^{56}$

Some of the KPMG partners were able to escape liability and some did not escape. Their motions for summary judgment were granted in part and denied in part. Summary judgment on the 1934 Act 10(b) claims was denied for three of the partners. Summary judgment on the 1934 Act $\S 10$ A claims was granted for all of the partners. ${ }^{57}$

\section{Millions of dollars of fictitious revenue at an IT firm in China}

Longtop Financial Technologies, Ltd. was founded in 1996 to provide information technology services to the banking and financial industry in China. Longtop grew from 500 employees in 2006 to over 7,000 in 2011. Derek Palaschuk became Longtop's chief financial officer (CFO) in 2006 and helped the company complete an initial public offering in 2007. Deloitte became Longtop's external auditor shortly before Palaschuk joined the firm. The CFO insisted that Deloitte should use alternative testing of Longtop's revenue contracts instead of mailed confirmations, the preferred procedure, and Deloitte relented. ${ }^{58}$

In 2010, an equity analysis firm independently analysed Longtop’s investment potential and noted several "red flags" in its financial statements: (1) excessive turnover of accounting employees; (2) use of a third party company to employ staff; and (3) the rushed and overpriced acquisition of a company called Giantstone. Later in 2010, an analyst at Needham \& Company LLC, an investment banking firm, expressed concern about Longtop's reported revenues from its largest customer, China Construction Bank. One of the bank's senior IT officials told him that the bank's contribution to Longmont's revenues was actually much less than the \$33 million that Longtop had reported in its income statement. When Longtop's CFO was confronted with this, he denied it. Nevertheless, Needham downgraded Longtop’s stock to "hold” instead of "buy."59

The CFO and other Longtop officials met with Deloitte in late 2010 to discuss market rumors that: (1) Longtop had inflated revenue from Construction Bank; (2) Longtop’s profit margins were suspiciously higher than its competitors; (3) Longtop had paid excessive large amounts to acquire several companies; and (4) Longtop was using a third party human resources company to employ most of its staff. In the meeting, Deloitte stated it had seen no indicators of fraud or inaccuracy in the revenues. However, the auditor suggested that Longtop should hire an independent third party to investigate the concerns discussed in the meeting. Longtop's management responded: "As there are no indications of fraud or internal control problems, an independent investigation is unnecessary.” Deloitte did not object to its client's decision. Longtop's management was pleased when shortly afterwards, BMO Capital Markets, a financial services provider, gave Longtop stock a rating of "outperform" and concluded that fears that the firm's revenues are exaggerated are probably

\footnotetext{
${ }^{56}$ Id. at $355,364-65$.

${ }^{57}$ Id. at 392.

58 In re Longtop Financial Technologies, Ltd. Securities Litigation, 32 F.Supp.3d 464 (S.D. N.Y. 2014).

${ }^{59} \mathrm{Id}$.
} 
overblown. ${ }^{60}$

In 2011, an investor forwarded to Palaschuk an anonymous report posted on the internet which disputed the accuracy of the firm's reported revenues. The author of the report noted that revenues from the top customers could not be verified, the gross margins did not seem realistic, and the income and the cash figures were greatly inflated. Longtop had reported a gross margin of 69\%, and its competitors reported gross margins only in the range of $15 \%$ to $50 \%$. The report explained in detail why Longtop's revenues from the Construction Bank could not be correct and opined that Longmont was "simply forging contracts.” The report contained several other red flags, including Longtop's third-party staffing, questionable acquisitions, and suspicious management stock sales and gifts. In conclusion, the report stated "a number of Chinese frauds have been exposed recently and I think this could be the next one to fall., ${ }^{\prime 1}$

Another stock commentary firm, Citron Research, issued a report on Longtop in 2011 that repeated many of the concerns contained in the anonymous report. Citron was concerned with Longtop’s "spectacularly high margins,” unconventional staffing model, large stock gifts from Longtop management to employees, and inflated revenue from the largest customers. Citron was also concerned with the previous high-profile lawsuit against Longtop’s top management for unfair business practices. Citron concluded that Longtop had "all the markings of a complete stock fraud" and that "every financial statement from Longtop's IPO to this date is fraudulent."

On April 28, 2011, Longtop held a conference call for investors to address the allegations in the Citron Report and other market rumors. The CFO, Paluschuk, directed the call and unequivocally denied the "absolutely false allegations of fraud and other alleged wrongdoings" in the analyst reports. ${ }^{62}$

Lian Wiezhou, Longmont's CEO, told Paluschuk during May 18-20 of 2011 that Longmont had been a fraud since 2004. Although the company had reported significant profits, in fact the company had never earned a profit. Lian admitted to Paluschuk that Longtop had far more debt that what had been disclosed in its balance sheet and that the cash balance was only \$131 million instead of the \$421 million that was reported. Continuing, Lian stated that about $40 \%$ of the reported revenue was "not real" and that the accountants working in China were also aware of the fraud. ${ }^{63}$

The New York Stock Exchange halted trading of Longmont stock on May 19, 2011 and the CFO, Palaschuk, resigned on the same day. On May 22, Deloitte resigned as auditor because of: (1) recently identified falsity of Longtop's financial records regarding cash, loan balances and sales; (2) deliberate interference from management in the auditing process; and (3) Longmont's unlawful retention of the audit files. When Deloitte asked Longtop's Chairman who was involved in the fraud, the Chairman replied, "senior management.” Longmont shareholders filed a class action in federal court against Longmont, its former CEO and CFO, and Deloitte, the former auditor. Plaintiffs grounded their lawsuit in the Securities and Exchange Act

$\S 10(\mathrm{~b})$, § 20 and Rule 10b-5. Plaintiffs alleged that the CFO made materially false and misleading statements regarding Longmont's financial statements (cash balance, loan balances, profit margin, revenue, and other financial metrics and irregularities) and the internal controls. The CFO allegedly made the misleading statements in conference calls with investors as well as through Longtop's public filings and press releases.

\footnotetext{
${ }^{60} I d$.

${ }^{61}$ Id.

${ }^{62} \mathrm{Id}$.

${ }^{63} \mathrm{Id}$.
} 
Plaintiffs alternatively sought to hold the CFO liable as a control person for false and misleading statements made by Longtop. ${ }^{64}$

Defendants Deloitte and the CFO separately filed motions to dismiss. Deloitte's motion was granted, but the CFO's motion was denied. Plaintiffs moved for a default judgment against the CEO and Longtop because they failed to appear, and the default judgment against those parties was granted. ${ }^{65}$

Palaschuk, the CFO, moved for a summary judgment, citing the following evidence: (1) the auditor Deloitte's unqualified opinions of Longtop's financial statements; (2) a due diligence report which confirmed the accuracy of the overriding majority of Longtop's bank balances; (3) the CFO's personal instruction to Deloitte to get confirmations of account balances from the banks; and (4) plaintiffs failed to identify specific steps that he could have taken to prevent the fraud. ${ }^{66}$

Under § 10(b), a plaintiff must prove: (1) a material misrepresentation or omission by defendant; (2) scienter; (3) a connection between the misrepresentation or omission and the purchase or sale of a security; (4) reliance upon the misrepresentation or omission; (5) economic loss; and (6) loss causation. Under Rule 10b-5, the maker of statement is the person or entity with ultimate authority over the statement, including its content and whether and how to communicate it. The required level of scienter under § 10(b) is either "intent to deceive, manipulate or defraud" or "reckless disregard for the truth." To show reckless disregard, plaintiffs must show that defendants have engaged in conduct "which is highly unreasonable and which represents an extreme departure from the standards of ordinary care to the extent that the danger was either known to the defendant or so obvious that the defendant must have been aware of it." ${ }^{, 67}$

The court denied the CFO's motion for summary judgment. The court found that a reasonable jury could find that Palaschuk failed to adequately investigate cash balances and reported the Construction Bank revenues notwithstanding multiple analyst reports challenging them. The court also noted that the CFO was aware of multiple reports that the Construction Bank revenues were inflated, but he failed to check directly with the bank to confirm them. With respect to both cash balances and inflated revenues, a jury could well find that the CFO recklessly failed to check information he had a duty to monitor. Even if the CFO presents a strong case, the question of his scienter is for the jury, and not a judge, to decide. ${ }^{68}$

\section{Auditor not liable to third party victim of Ponzi scheme because of}

strict pleading requirements pursuant to Private Securities Litigation Reform Act

Acting through firms they controlled, Paul Greenwood, Stephen Walsh and others conducted a fraudulent investment scheme during 1996-2009. These entities were involved: WG Trading Company (WGTC), a registered broker-dealer; Westridge Capital Management, Inc. (WCM), a registered investment adviser; WG Trading Investors, L.P. (WGTI), an unregistered “investment vehicle;" and WGIA LLC (WGIA), an entity created specifically to facilitate the investment of one of its clients, the Iowa Public Employees' Retirement System (IPERS). ${ }^{69}$

To perpetrate their fraud, Greenwood and Walsh obtained investments from numerous institutional investors, such as public pensions, educational institutions and retirement plans, encouraging them to (1)

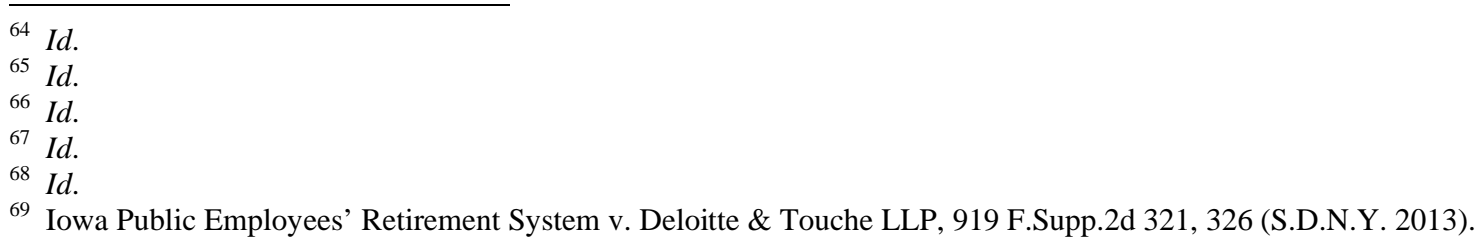


purchase a limited partnership interest in WGTC; (2) purchase a promissory note from another entity that was a limited partner of WGTC, such as WGTI; or (3) purchase shares in a "feeder fund," which would purchase a promissory note from WGTI, purportedly on the investor's behalf. WGTC was the apparently legitimate face of all these entities, as investors were told that it would invest their funds. ${ }^{70}$

Greenwood and Walsh did not manage investors' funds as promised, and instead, stole millions of dollars for their own personal use. For a number of years, they were able to maintain the illusion of profitability by creating a Ponzi scheme. They used new investors' funds to pay their earlier investors; they engaged in commingling of the funds; they created fraudulent account statements; and they charged investment fees based on the fictitious earnings. ${ }^{71}$

Plaintiff IPERS first invested \$400 million with WCM in 2007, which funneled \$337 million of that money to WGTC. Plaintiff did not have a direct limited partnership investment in WGTC; instead, plaintiff was indirectly partnered with the entity because plaintiff purchased a promissory note issued by WGIA in the same amount, which WGIA then utilized to purchase the partnership interests in WGTC. In 2008, plaintiff invested an additional $\$ 100$ million using the same procedure. By 2009, plaintiff's total investment amounted to about $\$ 500$ million. $^{72}$

In 2009, the Ponzi scheme was discovered after Greenwood and Walsh refused to submit to an audit by the National Futures Association (NFA), and the NFA suspended them from trading and notified the SEC. The SEC launched an investigation and the fraud was uncovered. The SEC charged WGTI with violations of the Securities Act of 1933, the Securities and Exchange Act of 1934, and the Investment Advisers Act of 1940 and an emergency asset freeze was issued against Greenwood and Walsh. Those two were charged with several crimes and civil offenses. ${ }^{73}$

The district court appointed a Temporary Receiver to take control of the investment firms' assets and to reimburse investors. The Receiver was able to find $\$ 800$ million of funds held by those firms and it returned that money to the investors. Overall, the investors were able to recover $85 \%$ of their claims. After recovering the majority of the invested funds, plaintiff was short by $\$ 38$ million, plus $\$ 1$ million in fee payments. Accordingly, plaintiff sued the investment firms’ auditor, Deloitte \& Touche (D\&T), for $\$ 39$ million. $^{74}$ During fiscal years 2001 through 2007,

D\&T served as the external auditor for WGTC, issuing unqualified opinions on the financial statements during that period. D\&T contended that those financial statements had followed GAAP and that they had applied GAAS in their audit. Also, D\&T stated that WGTC had no material weaknesses in its internal control. ${ }^{75}$

In its complaint, plaintiff alleged that D\&T's “auditing practices were so deficient that the audits amounted to no audit at all., ${ }^{, 76}$ Plaintiff noted that the ease by which the SEC discovered the fraud highlights the D\&T's failure. Plaintiff stated that the auditor's failure to see the obvious and to follow up on numerous red flags constituted behavior that no reasonable auditor would have engaged in. The red flags included: (1) WGTC had assigned all of the accounting and internal control responsibilities to only one employee; (2) WGTC and

\footnotetext{
${ }^{7}$ Id.

71 Id. at 327.

${ }^{72} \mathrm{Id}$.

${ }^{73} \mathrm{Id}$.

${ }^{74}$ Id.

$75 \mathrm{Id}$. at 328.

${ }^{76} \mathrm{Id}$.
} 
WGTI received funds from each other's investors; (3) WGTC paid employee advances to Greenwood and Walsh, charging them as reductions of WGTI's capital in WGTC, rather than increases of its investment in WGTC; (4) WGTI did not enter its transfers of bank interest income to WGTC from 2006 to 2008, but WGTC still recorded these receipts as income; (5) WGTC gave WGTI the difference between actual monthly net income/loss and the net earnings allocated to its other limited partners, which were recorded by WGTI as an increase in its investment in WGTC; (6) numerous abnormalities connected to WCM's monthly investment portfolio summary, which it mailed to investors; and (7) many related party transactions involving the movement of funds between WGTC and WGTI, with associated tax abnormalities, commingling of funds, and improper allocation of performance fees. In summary, plaintiff's complaint stated "since it was obvious, from the accounting books and records of WGTC, that WGTC and WGTI were being operated as a single entity, it was impossible for D\&T to express a clean audit opinion concerning WGTC without having properly audited the inter-partnership account of WGTI in the accounting books and records of WGTC."77 Accordingly, plaintiff's two claims in the complaint are that defendant D\&T: (1) committed securities fraud; and (2) breached its fiduciary duty under a theory of aiding and abetting. ${ }^{78}$

D\&T responded by filing a motion to dismiss based on two grounds: (1) with respect to Rule 10b-5, the complaint failed to allege a false statement made by D\&T or WGTC with sufficient particularity, or, alternatively, did not establish an inference of scienter; and (2) plaintiff failed to adequately plead its claim of aiding and abetting the fraud. ${ }^{79}$ The Private Securities Litigation Reform Act (PSLRA) requires strict pleading requirements regarding particularity and scienter in securities cases..$^{80}$ In the context of Rule $10 \mathrm{~b}-5$ and $\S 10$ (b), to state a claim a plaintiff must plead that (1) defendant made a false statement or material omission; (2) defendant did so with scienter, which is an intent to deceive, manipulate or defraud; and (3) plaintiff relied on the statement or omission, causing the plaintiff injury. ${ }^{81}$ Furthermore, the PSLRA requires a plaintiff to state with particularity facts giving rise to a strong inference that defendant acted with the required state of mind, and such an inference of scienter must be as least as compelling as any opposing inference of nonfraudulent intent. $^{82}$

The court granted defendant D\&T's motion to dismiss, with prejudice. ${ }^{83}$ The court noted that if an auditor is "not aware of facts indicating that a transaction was suspicious, or part of a fraud, the auditor's failure to investigate the transaction — even if negligent—does not provide a basis for a fraud claim., ${ }^{\text {"4 }}$ In the context of red flags, courts have also noted that an auditor's access to the information by which it could have discovered the fraud is not sufficient to establish recklessness. Auditor access is not the same as auditor awareness. In this context, a previous court used the following example: merely because a person has access to every book in a library does not mean that he has read and chosen to ignore facts contained in a particular book in the library. Therefore, merely alleging that the auditor had broad access to the client's operations at best supports an inference that the auditor was negligent, and more likely supports nothing at all. ${ }^{85}$ With respect to plaintiff's

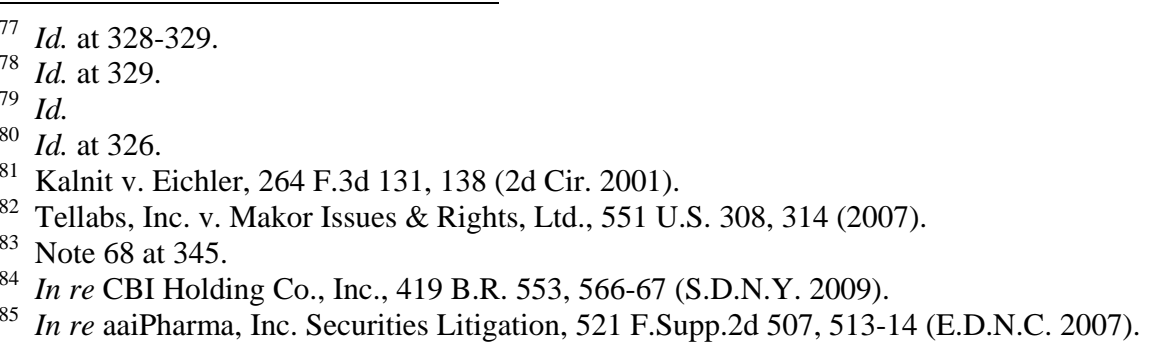


aiding and abetting claim, although plaintiff pleaded sufficient facts to raise an inference of fraud, it failed to plead the auditor's state of mind with enough particularity. The facts stated in the complaint failed to support an inference that the auditor was reckless, let alone willfully blind to the fraud. While D\&T may have been negligent, the allegations in the complaint did not establish that it was a conscious wrongdoer. Therefore, plaintiff's aiding and abetting claim was also dismissed. ${ }^{86}$

\section{Dow Chemical Company's fraud investigator, wrongfully discharged after reporting improper capitalisation of expenses, sued Dow pursuant to whistleblowing provision of Sarbanes-Oxley Act}

In 2014, plaintiff Kimberly Wood filed her complaint against three defendants: Dow Chemical Company (Dow); Andrew Liveris, Dow's CEO; and Charles Kalil, Dow's general counsel. Wood alleged a single claim: that her employment was terminated in retaliation for whistleblowing pursuant to the Sarbanes-Oxley Act. Wood had worked for Dow for twenty-five years, first in international accounting, then in financial instruments accounting, and eventually as a fraud investigator. She held CMA and CFE credentials. ${ }^{87}$

While working as a fraud investigator, she assisted in numerous investigations relating to fraud against shareholders, Dow's code of conduct and other policies. In her complaint, Wood highlighted seven investigations she took part in and reported on: (1) a construction project for the H Hotel which exceeded budget by $\$ 13$ million and resulted in the retaliatory termination of a Dow employee; (2) unreported personal expenditures made by Dow for the CEO, which led to Liveris reimbursing Dow after her report; (3) further personal expenses of Liveris that were paid by Dow but were not reimbursed; (4) payments by Dow, at the CEO's direction, to The Hellenic Initiative (THI), Liveris' personal charity, and payments to Prinkipos, a charity owned by the Greek Orthodox Church; (5) the CEO's excessive use of the Dow corporate jet and further involvement of Liveris and Dow's funds with the Greek Orthodox Church and Prinkipos; (6) improper accounting practices on the Olefins II project to hide cost overruns; and (7) financial statement fraud with the Olefins II project. ${ }^{88}$ In the Olefins II project, Wood reported multiple instances of accounting misstatement. Project managers were purposefully moving expenses to capital to hide cost overruns with the approval of senior management. $^{89}$

Wood alleged that after she had proven herself to be a thorough investigator by conducting the investigations and reporting her findings, defendants threatened her and tried to intimidate her. Wood stated she began to be assigned to a lesser number of investigations and later learned the CEO wanted to fire her. On October 13, 2013 - the day after she reported the financial statement fraud in the Olefins II project-she was told that she would be terminated effective October 31, $2013 .^{90}$

Wood's complaint alleged that Dow retaliated against her after she reported wrongful acts to management. To prevail on a claim of retaliation, the plaintiff must show that: (1) he or she engaged in a protected activity; (2) the employer knew that plaintiff engaged in a protected activity; (3) plaintiff suffered an unfavorable personnel action; and (4) the protected activity was a contributing factor in the unfavorable action. ${ }^{91}$

After Wood filed her complaint, defendants filed a motion to dismiss and alleged that plaintiff failed to

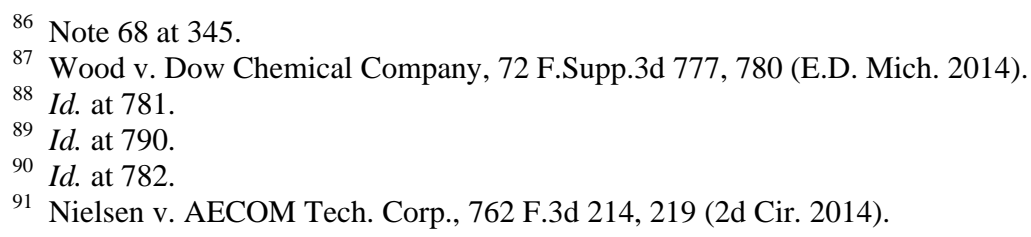


show in her complaint the existence of the four elements of retaliation just enumerated. The court found that Wood's reporting of the financial statement fraud - the event which led directly to her termination-was protected activity pursuant to the whistleblowing provision of the Sarbanes-Oxley Act and that the first of the four elements was satisfied. ${ }^{92}$ The court found the second element was satisfied because Wood had alleged sufficient facts in her complaint from which it could be inferred that the CEO had knowledge of her protected activities and played a role in her termination. ${ }^{93}$ The third element was met because Wood was terminated. And the fourth element was satisfied because of the temporal proximity between Wood's reporting of the financial statement fraud and notice of her termination one day later. ${ }^{94}$

Accordingly, Wood had properly pled a claim for retaliatory discharge and the court denied defendants' motion to dismiss. ${ }^{95}$ However, this case never went to trial because the parties reached an out-of-court settlement in February, 2015. ${ }^{96}$

In April, 2016, Dow stockholder S.M. Levine filed a derivative action on behalf of Dow Chemical Company against Liveris, the CEO. ${ }^{97}$ Representing the interests of the firm and its shareholders, Levine alleged that the CEO had misused corporate assets and he cited Kimberly Wood's investigatory reports. ${ }^{98}$ In response, the CEO filed a motion to dismiss and the motion was granted. The court found that plaintiff had not adequately stated facts in his complaint to support his claim that Dow's Board of Directors had not properly investigated the alleged misuse of assets. ${ }^{99}$

\section{Corporate officers not liable to shareholders for financial}

statement fraud if they had no knowledge of the fraud

A group of shareholders of Peregrine Systems, Inc. (Peregrine) filed a derivative action against several members of Peregrine's board of directors and employees, its outside auditor and two of its former business partners. The lawsuit alleged that plaintiffs had been induced to hold Peregrine stock during 1997-2002 by Peregrine's false, fraudulent and misleading financial statements and incurred losses as a result. ${ }^{100}$ The complaint stated that defendants engaged in a fraudulent financial scheme to inflate Peregrine's stock price and that the fraud centered on the recording of hundreds of millions of dollars of revenue despite non-binding arrangements with customers, in violation of GAAP and Peregrine's own revenue recognition policy. ${ }^{101}$

Defendants filed a motion for summary judgment at the trial court, the trial court granted defendants' motion, the case was dismissed, and plaintiffs appealed. The court held that, although financial statement fraud may have occurred, plaintiffs had failed to show that defendants had knowledge of the fraud and, therefore, could not be held responsible for the fraud. The Court of Appeals affirmed the trial court's ruling and the case was dismissed. ${ }^{102}$

In a related case, a derivative action was also brought by Peregrine shareholders against the corporation

\footnotetext{
${ }^{92}$ Wood v. Dow Chemical Company, Note 86 at 790.

${ }^{93}$ Id.

${ }^{94}$ Van Asdale v. Int'l Game Tech., 577 F.3d 989, 1003 (9 $9^{\text {th }}$ Cir. 2009).

95 Wood v. Dow Chemical Company, Note 86 at 796.

${ }^{96}$ Levine v. Liveris, 216 F.Supp.3d 794, 801(E.D. Mich. 2016).

97 Id. at 799.

${ }^{98} \mathrm{Id}$. at 802.

99 Id. at 815.

100 Bains v. Moores, 172 Cal.App. $4^{\text {th }} 445$, 449 (Cal.App. 2009).

101 Id. at 451.

102 Id. at 486.
} 
itself, also alleging financial statement fraud. ${ }^{103}$ That case was later settled for all of the shareholders who had joined the class action. ${ }^{104}$ However, some had opted out of the class and had the right to bring suit on their own. ${ }^{105}$

\section{Financial statement fraud is not uncommon in bankruptcy cases}

It is not uncommon for a voluntary debtor or an involuntary debtor in a bankruptcy action to present fraudulent personal or business financial statements to the court in an attempt to hide assets or otherwise to defraud his creditors. ${ }^{106}$

\section{Conclusions}

The financial statement fraud literature indicates that, in order to better assess fraud risk in audit planning, an auditor needs to be aware of the variety of fraud schemes, the specific techniques used in those schemes, and the most common methods that fraudsters have employed to conceal them. Accordingly, the researcher analysed selected U.S. federal district and appellate court cases of financial statement fraud decided during the past twenty years. The study of those cases led to these conclusions: (1) financial statement fraud is defined as the deliberate misstatement or omission of amounts or disclosures of financial statements to deceive financial statement users, especially investors and creditors; (2) U.S. statutes and regulations used to prosecute financial statement fraudsters include the Securities Act of 1933, Securities and Exchange Act of 1934, SEC Rule 10b-5, Investment Advisers Act of 1940, Private Securities Litigation Reform Act, and the Sarbanes-Oxley Act; (3) the most significant financial statement fraud schemes during the past twenty years included use of unconsolidated special-purpose entities to conceal debt, improper immediate revenue recognition in leasing of bandwidth in the telecom industry, improper capitalisation of operating expenses, improper accounting for goodwill in a merger, failure to write off a large amount of bad receivables, excessive recognition of revenue in bundled leases in the photocopier industry, improper use of loss contingency reserves to inflate current income, use of fictitious revenue to overstate earnings, and improperly and purposefully moving a project's operating expenses to capital in order to hide cost overruns; (4) in order to be held legally liable for financial statement fraud, a corporate officer is required to have knowledge of the financial statement fraud; and (5) an employee discharged after reporting a case of financial statement fraud may sue under the whistleblowing provisions of the Sarbanes-Oxley Act by showing she engaged in protected activity, management knew of the protected activity, she suffered an unfavorable personnel action, and the protected activity was a contributing factor in the discharge.

\section{References}

Ajekwe, C. C. M., \& Ibiamke, A. (2017). Accounting frauds: A review of literature. IOSR Journal of Humanities and Social Science, 22(4), 42-43.

Albrecht, C., Albrecht, W., \& Dunn, J. (2001). Conducting a pro-active fraud audit: A case study. Journal of Forensic Accounting, (2), 203-218.

Beasley, S. M., Carcello, J. V., \& Hermanson, D. R. (2010). Fraudulent financial reporting: 1997-2007: An analysis of U.S. public companies. Research Report. Committee of Sponsoring Organizations of the Treadway Commission (COSO). Retrieved from https://www.coso.org/Documents/COSO-Fraud-Study-2010-001.pdf

103 In re Peregrine Systems, Inc. Securities Litigation, No. 02-CV-870 (S.D.Cal. filed May 6, 2002).

104 Hildes v. Arthur Andersen LLP, 734 F.3d 854, 858 ( $9^{\text {th }}$ Cir. 2013).

105 Id. at 854

106 See, e.g., In re Colon, 558 B.R. 563, 589 (D. Puerto Rico 2016). 
Bonner, S. E., Palmrose, Z. V., \& Young, S. M. (1998). Fraud type and auditor litigation: An analysis of SEC accounting and auditing enforcement releases. The Accounting Review, 73(4), 503-532.

CNN Library. (2013). Enron fast facts. Retrieved April 23, 2018, from https://www.cnn.com/2013/07/02/us/enron-fast-facts/index.html

Gao, L., \& Srivastava, R. P. (2008). The anatomy of management fraud schemes: Analyses and implications. Working Paper, University of Nebraska and University of Kansas.

Heiman, V. (1990). Auditors' assessment of the likelihood of analytical review explanations. The Accounting Review, (65), 870-890.

Libby, R., \& Frederick, D. M. (1990). Experience and the ability to explain audit findings. Journal of Accounting Research, 28(2), 348-367.

Loebbecke, J., Eining, M., \& Willingham, J. (1989). Auditor's experience with material irregularities: Frequency, nature and detectability. Auditing: A Journal of Practice and Theory, 9(Fall), 1-28.

Nelson, M. W., Elliott J. A., \& Tarpley, R. L. (2003). How are earnings managed? Examples from auditors. Accounting Horizons, 17(Supplement), 17-35.

Rezaee, Z. (2002). Causes, consequences and deterrence of financial statement fraud. Critical Perspectives on Accounting, 16(3), 277-298.

Smith, J. F., \& Kida, T. (1991). Heuristics and biases: Expertise and task realism in auditing. Psychological Bulletin, 109(3), 472-489.

Spathis, C., Doumpos, M., \& Zopounidis, C. (2002). Detecting falsified financial statements: A comparative study using multicriteria analysis and multivariate statistical techniques. The European Accounting Review, 11(3), 509-535.

Wells, J. T. (2014). Principles of Fraud examination (4th ed.). Hoboken, N.J.: John Wiley \& Sons, Inc. 